\title{
REFRACTORY GASTROESOPHAGEAL REFLUX DISEASE
}

\author{
Joaquim Prado P. MORAES-FILHO*
}

\begin{abstract}
Context - Gastroesophageal reflux disease (GERD) is a condition which develops when the reflux of stomach contents causes troublesome symptoms and/or complications. Its pathophysiology, diagnosis and treatment have frequently been analyzed but it is interesting to review some aspects of the GERD refractory patients to the proton pump inhibitors treatment. The treatment encompasses behavioral measures and pharmacological therapy. The majority of the patients respond well to proton pump inhibitors treatment but $20 \%-42 \%$ of them may not do so well. Patients who are unresponsible to $4-8$ weeks' treatment with proton pump inhibitors (omeprazole, pantoprazole, rabeprazole, lansoprazole, esomeprazole, pantoprazole-Mg) might have so-called refractory GERD. Results - In some cases the patients are not real refractory because either they do not have GERD or the disease was not correctly treated, but the term refractory is still employed. Although debatable, the Brazilian GERD Consensus based upon evidences recommends as first step in the diagnosis, the upper digestive endoscopy to exclude the diagnosis of peptic ulcer and cancer and in some cases identify the presence of esophageal mucosa erosions. Conclusions - The main causes of the so-called refractory GERD are: (1) functional heartburn; (2) low levels of adherence to proton pump inhibitors treatment; (3) inadequate proton pump inhibitors dosage; (4) wrong diagnosis; (5) co-morbidities and pill-induced esophagitis; (6) genotypic differences; (7) nonacid gastroesophageal reflux; (8) autoimmune skin diseases; (9) eosinophilic esophagitis.
\end{abstract}

HEADINGS - Gastroesophageal reflux, drug therapy. Proton pump inhibitors.

\section{INTRODUCTION}

Gastroesophageal reflux disease (GERD) is a condition that develops when the reflux of stomach contents causes troublesome symptoms and/or complications ${ }^{(20)}$. GERD prevalence is high, occurring in $12 \%$ to $20 \%$ of the urban population in Brazill(14), a figure equivalent to that in other countries.

The importance of GERD has been emphasized as, in addition to its morbidity, there is a significant limitation to the health-related quality of life, such as permanent discomfort to the patient with repeated visits to the doctor, as well as high costs of exams and treatment ${ }^{(7)}$.

There is no diagnostic marker for the disease and so the diagnosis is sometimes difficult, considering that the upper digestive endoscopy only provides a diagnosis when esophageal mucosa erosions are observed, which occurs in only $1 / 3$ of cases.

The clinical treatment showed considerable improvement with the introduction of proton pump inhibitors (PPIs), which provide effective gastric acid secretion blockade (Figure 1). PPIs are usually prescribed at standard doses and given in the morning for a period of 4 to 8 weeks $^{(16)}$. Despite being a successful treatment in the majority of patients, PPI therapy failure may occur. In fact, unfortunately $20 \%$ to $42 \%$ of the cases may not respond to PPI therapy, with persistence of reflux symptoms or even the occurrence of new symptoms and esophagitis ${ }^{(2)}$.

The present review presents and discusses the causes to GERD refractory to clinical treatment with PPIs. However it is worth mentioning that the term refractory may not be adequate in some cases, as it is not always a true treatment failure, but sometimes a diagnostic error, non-compliance to the proposed treatment or inadequate dose, etc. When treating a non-responsive patient, the physician's first consideration should be to wonder whether the PPI potency was enough for gastric acid neutralization. This is

\begin{tabular}{|lc|}
\hline Proton pump inhibitor (PPI) & Standard dose (mg/day) \\
\hline Omeprazole & 40 \\
Lansoprazole & 30 \\
Rabeprazole & 20 \\
Pantoprazole & 40 \\
Esomeprazole & 40 \\
Pantoprazole- $\mathrm{Mg}$ & 40 \\
\hline
\end{tabular}

The main causes of the lack of response to PPI therapy are shown in Figure 3

FIGURE 1. Proton pump inhibitors

Declared conflict of interest: Medley, Reckitt-Benckiser, Takeda.

Associate Professor of Gastroenterology - University of Sao Paulo School of Medicine. Correspondence: Prof. Joaquim P.P. Moraes-Filho - Rua Itapaiuna, 1165 - casa 28 - 05707-001 - São Paulo, SP, Brazil. E-mail: joaquim.prado@uol.com.br / joaquim. prado@usp.br 
certainly one of the cases of unsuccessful treatment, but other factors may also occur. Consequently, a careful review of the possible mechanisms of treatment failure, including the diagnosis, is required.

\section{DIAGNOSIS (Figure 2)}

\section{Upper digestive endoscopy (UDE)}

The usefulness of initially performing the UDE in GERD in young adult patients (younger than 40 years of age) with typical symptoms of GERD has been questioned, as it does not change the clinical management of the disease and may not disclose any important findings. However, at the III Brazilian Consensus on GERD using evidence-based medicine, the role of UDE as the first approach for GERD-suspected patients has been emphasized ${ }^{(16)}$. The UDE is important as it can establish the diagnosis of erosive esophagitis, although this presentation is less frequent than non-erosive reflux disease (NERD). Peptic ulcer can be excluded, as well as the less likely esophageal or gastric cancer. Thus, the first test that should be performed in patients with refractory GERD is UDE.

\section{Prolonged pH-metry}

The esophageal 24-hour pH-metry is the next test of choice for patients with refractory GERD, while on twice-daily PPI therapy. However, it should be taken into consideration that the esophageal 24-hour $\mathrm{pH}$-metry is no longer considered the gold standard test for reflux.

It is usual to suggest that patients with refractory GERD have nonacid gastroesophageal reflux. However,

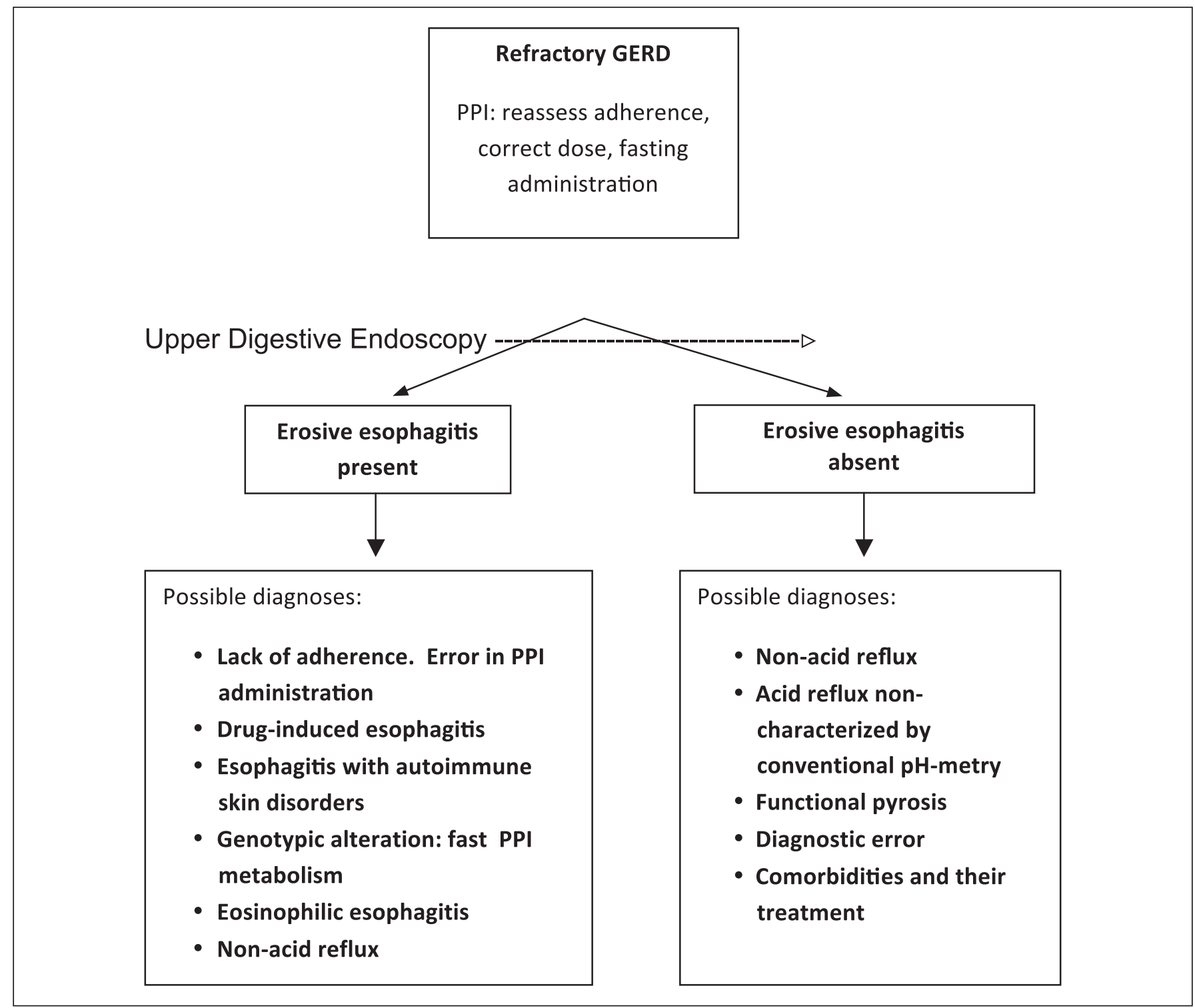

FIGURE 2. Diagnostic conduct in refractory GERD (Richter ${ }^{(17)}$ modif.) 
other diagnoses need to be considered, which might be more common. As such, before attributing the reflux to a nonacid component, it should be remembered that these patients may really have acid reflux that was not characterized by the conventional 24-hour $\mathrm{pH}$-metry test. The patient may present normal findings one day and abnormal findings the next day: $25 \%$ of the cases monitored by a telemetric capsule ("Bravo" system) that were previously considered normal by conventional 24-hour $\mathrm{pH}$-metry test, when studied for 48 hours showed pathological patterns of acid esophageal reflux $^{(8)}$. Therefore, the ideal condition would be to test the reflux with the telemetric capsule for 48 hours, which is not possible in an everyday situation.

\section{Other diagnostic methods}

The development of investigative tests, such as the study of reflux by impedance/pH-metry, high-resolution esophageal manometry and gastric scintigraphy will probably contribute to better identify GERD. Such more sophisticated methods, however, are in our country more often associated with research laboratories, with some exceptions in large private centers. Unfortunately, they are not yet available in most Brazilian centers, particularly for patients treated at the public health system and therefore will not be discussed here in further details.

\section{CAUSES OF TREATMENT FAILURE}

As reported, although most reflux patients respond satisfactorily to PPIs, a figure of $20 \%$ to $42 \%$ may be considered "difficult to treat", as they show no significant results to the initial treatment with PPIs. In such cases, there are several possibilities that may explain the difficulty to treat such patients, which are shown in Figure 3.

\footnotetext{
- Functional pyrosis

- Lack of adherence to the pharmacotherapeutic treatment

- Wrong or inadequately prescribed PPI doses

- GERD misdiagnosis

- Diagnostic error due to comorbidities and/or their treatment Drug-induced esophagitis

- Genotype differences that confers altered capacity to metabolize PPI

- Nonacid gastroesophageal reflux

- Autoimmune skin diseases

- Eosinophilic esophagitis
}

FIGURE 3. GERD therapy with PPI: main causes of failure

\section{Functional pyrosis}

Functional pyrosis is part of the picture of the so-called "diagnostic errors", as its symptoms mimic GERD and may induce misdiagnosis. In such cases, the clinical complaints suggesting GERD may not necessarily be related to acid reflux and should be considered indicative of other diagnoses such as achalasia, gastroparesis or functional pyrosis. Of these functional pyrosis is relatively more frequent, being defined as the presence of heartburn episodes occurring in the absence of gastroesophageal reflux, motility alterations or structural morphological abnormalities. It is caused by increased esophageal sensitivity and therefore, esophageal perception to the presence of acid $^{(10)}$.

The functional course of visceral hypersensitivity may occur in association with organic diseases such as GERD itself and in these cases, the clinical condition of the latter can be very intense. On the other hand, functional pyrosis in the absence of GERD can mimic the latter, when in fact it is essentially a functional alteration, where the administration of PPIs, even at higher doses, is not usually a suitable treatment conduct.

The pathophysiology of visceral hypersensitivity is complex and not completely understood, involving peripheral and central sensitivity as well as psycho-neuroimmunological interactions ${ }^{(10)}$. Visceral hypersensitivity often improve with the administration of pain modulators such as tricyclic antidepressants (e.g. amitriptyline) and selective inhibitors of serotonin reuptake (e.g. fluoxetine) at lower doses than those used as antidepressants ${ }^{(17)}$. Psychotherapy may also be beneficial, although there are no studies that allow its indication based on scientific evidence.

\section{Lack of treatment adherence. Inadequate PPI dose}

Outpatients with GERD treated at Clinics Hospital of the University of Sao Paulo School of Medicine, showed significant levels of nonadherence to treatment with PPIs $(47.5 \%)$, having as main causes the irregular drug intake, drug administration outside the ideal time period or even treatment withdrawal ${ }^{(6)}$. The recommendation therefore, is that treatment adherence should initially be investigated, which means verify whether the patient strictly and continuously follows the medical prescription.

In this regard, it is noteworthy the fact that the administration of PPIs should always be preceded for a period of at least 30 minutes before the food intake, as they in turn, stimulate the production of the proton pumps by the parietal cells, which will then be inhibited by the PPI action. This rule, however, is not always followed. In the United States, for example, about $70 \%$ of primary care physicians and $20 \%$ of gastroenterologists advise patients to take the evening dose of PPIs before bedtime and do not believe that the association between drug and food is really important ${ }^{(4)}$.

When symptoms persist and adherence to treatment has been confirmed, it is recommended to substitute the PPIs. An alternative that can precede PPI substitution is the prescription of a double dose of the drug (before breakfast and before dinner), a condition in which up to $25 \%$ of patients begin to have satisfactory clinical response. Therefore, those who show no improvement with the use of higher PPI dose for a period 4-8 weeks should be considered as patients with "refractory GERD"(17).

\section{Presence of comorbidities. Pill-induced esophagitis}

As with the prevalence of GERD, the frequency of comorbidities increases with age. In Clinics Hospital of Uni- 
versity of Sao Paulo, a tertiary-care hospital, it was observed that $87 \%$ of patients with mean a age of 55 years had some associated comorbidity. The more frequent are: hypertension, dyslipidemia, obesity, depression, diabetes and arthrosis ${ }^{(15)}$. Visceral sensitivity can be altered in these conditions and, on the other hand, the drugs used for treatment of the comorbidities may also be complicating factors in the therapeutic response to PPIs, depending on the digestive adverse events.

Figure 4 shows some examples of drugs used for these diseases and their main adverse events in the upper gastrointestinal tract.

\begin{tabular}{|ll|}
\hline $\begin{array}{l}\text { Drug / indication } \\
\text { statins / } \\
\text { hypercholesterolemia } \\
\text { enalapril / arterial } \\
\text { hypertension }\end{array}$ & $\begin{array}{l}\text { Adverse event } \\
\text { sibutramine / obesity }\end{array}$ \\
$\begin{array}{l}\text { nausea, abdominal pain, dyspepsia, } \\
\text { fluoxetine / depression }\end{array}$ & nausea, vomiting \\
$\begin{array}{l}\text { metformin / diabetes } \\
\text { mellitus }\end{array}$ & nausea, vomiting, dry mouth \\
$\begin{array}{l}\text { non-steroidal anti- } \\
\text { inflammatory drugs / } \\
\text { arthrosis }\end{array}$ & $\begin{array}{l}\text { epigastralgia, nausea, vomiting, } \\
\text { dyspepsia, g.i. hemorrhage, } \\
\text { peptic ulcer }\end{array}$ \\
\hline
\end{tabular}

FIGURE 4. More common medications used in the comorbidities associated to GERD and their principal adverse events in the upper digestive tract

The routine ingestion of tablets/pills may itself constitute a problem, particularly in children and elderly patients. In the elderly, medication-induced esophagitis can lead to chronic complaints due to complications of esophageal motor changes or even undiagnosed stenosis. Endoscopic evaluation shows the presence of one or more changes surrounded by normal mucosa and the occurrence of diffuse inflammation, whitish exudate, fibrotic stenosis and even organ perforation have also been reported. The most common site of esophageal injury caused by pill ingestion is at the junction between the proximal and middle third of the organ, where the amplitude of peristaltic waves is relatively low and the esophagus is compressed by the aortic $\operatorname{arch}^{(1)}$. The main drugs in tablet/pill presentation that might induce esophagitis are shown in Figure 5.

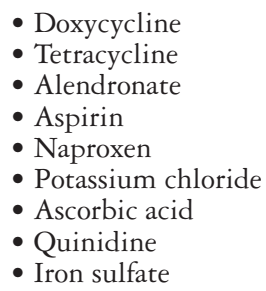

FIGURE 5. Main esophagitis-inducing medications administered as pills

The management in these cases consists essentially in the withdrawal of the pill/tablet inducing inflammation in the esophageal mucosa, and treatment with proton pump inhibitors or sucralfate. The stenosis cases require dilatation. Preventive care is important: the patients in general, especially the elderly, should always take the pills/tablets with a glass of water and not lie down within at least one hour after the ingestion.

\section{Genotypic differences: resistance to acid suppres- sion}

PPIs are metabolized in the liver by cytochrome P450 2c. Although genotypic differences between patients are relatively infrequent, genetic variations may occur regarding the capacity to metabolize PPIs by P450, i.e., the velocity at which PPIs are metabolized. Thus, individuals who are "fast metabolizers" of PPIs show a lower decrease in gastric acidity and therefore lower rates of esophagitis healing. Differently, in the "slow" or "intermediate metabolizers" (9), the PPIs are metabolized more slowly and their action is longer-lasting. It is interesting to observe that the genetic pattern of rapid metabolism of PPIs is more common in Asians (12\%-20\%) than in the Caucasian western population $(3 \%-6 \%)^{(17)}$.

\section{Non-acid or weakly acid reflux}

Thanks to the new methodology represented by esophageal impedance, it is possible to measure the movement of liquids and gases within the esophagus. When the impedance is associated with $\mathrm{pH}$ ("pH-metry-impedance"), non-acid reflux can be quantitatively assessed (one should avoid using the term "alkaline reflux" or "bile reflux"). In this case, some cases labeled as "non-acid reflux" actually constitute weakly acidic reflux ( $\mathrm{pH}$ between 4.0 and 6.5) that occurs during the day ${ }^{(18)}$. Results of observation of patients with GERD undergoing treatment with PPIs administered twice daily, suggest that $20 \%-40 \%$ of them have non-acid reflux, which probably contributes to the persistence of symptoms ${ }^{(21)}$.

The management in these cases may be relatively complicated, as there is no conclusive evidence on the most appropriate treatment. Surgical intervention (fundoplication) could be considered the ideal solution for the treatment of cases of non-acid or weakly acid reflux. However, the role of antireflux surgery and also the clinical treatment have not yet been properly studied as Evidence-Based Medicine.

Advances in the treatment of these patients have been carried out with Baclofen ${ }^{(12)}$ and other GABA $_{B}$ receptor agonists with non-acid reflux improvement as well as symptoms associated with it. The adverse event profile of the drug, including dizziness and sleepiness has, however, limited its use. The new $\mathrm{GABA}_{\mathrm{B}}$ receptor agonists are promising drugs, currently being studied, such as lesogaberan and arbaclofen, which have a low profile of adverse effects on the central nervous system ${ }^{(5,11)}$.

\section{Autoimmune skin disorders}

Some autoimmune skin disorders may affect the esophagus such as epidermolysis bullosa, pemphigus vulgaris, cicatricial pemphigoid and lichen planus. Patients are usually middle-aged women who complain of heartburn and dysphagia (caused by proximal esophageal strictures). The 
skin lesions are not always characteristic of the disease. When esophagitis involves the formation of vesicles or blisters, mucosal biopsies should be submitted to direct and indirect immunofluorescence to attain the correct diagnosis ${ }^{(17)}$. Treatment should be instituted by a dermatologist as it is necessary to have experience with the immunosuppression that these cases may require.

\section{Eosinophilic esophagitis}

Eosinophilic esophagitis is a disorder characterized by several digestive symptoms that may be similar to those of GERD, such as dysphagia and vomiting. These occur in association with intense esophageal eosinophilia, which is not responsive to acid blockade. It is noteworthy the fact that many of these patients have GERD as the underlying disease, in association with eosinophilic esophagitis, while others have asthma or food allergies (especially milk, eggs, soy, peanuts or melon) $)^{(17)}$

The endoscopy usually discloses multiple rings or white spots of exudate on the mucosa. The definitive diagnosis is based essentially on histopathological examination of the esophageal biopsy: the fragments must have 15 to 20 or more eosinophils per high-magnification fields. Noteworthy is the fact that peripheral eosinophilia is uncommon in these cases ${ }^{(19)}$.

There are few treatment options such as the removal of allergens from the diet and the use of inhaled steroids such as fluticasone, properly administered (dissolved in the mouth) twice daily for a period of 3 months, with a substantial reduction in the number of eosinophils and symptom improvement $^{(13,19)}$. Moreover, significant results have been obtained with budesonide ${ }^{(19)}$. When the treatment with inhaled steroids is unsatisfactory, another possibility is the use of leukotriene D4 antagonists (montelukast) or oral prednisone ${ }^{(3)}$.

\section{CONCLUSIONS}

Patients with GERD who meet the criteria to be considered refractory to medical treatment, must first be submitted to endoscopy in order to exclude peptic ulcer disease and cancer, in addition to allow the diagnosis of mucosal erosions that characterize erosive esophagitis.

The possibility of non-adherence to treatment, misdiagnosis, drug-induced esophagitis, skin disorders or autoimmune eosinophilic esophagitis should be considered and appropriately excluded. Furthermore, there is a less likely possibility of the occurrence of a hypersecretion syndrome such as Zollinger-Ellison or a genotypic trait that involves the altered capacity to metabolize PPIs.

When endoscopic findings are normal, the investigation must be extended with the available resources. The 24-hour $\mathrm{pH}$-metry and, when appropriate, the pHmetry-impedance should be performed, considering that the observation time of 24 hours for the $\mathrm{pH}$-metry might possibly be not enough to characterize acid reflux ${ }^{(8)}$.

Considering the less frequent diagnosis of non-acid reflux, the clinical and/or surgical conduct is more difficult, as there are no studies that allow an evidence-based decision. Yet, from the clinical point of view, the use of sucralfate or cholestyramine can offer good results, as well as the fundoplication performed by an experienced surgeon.

One should not forget to consider the less frequent hypothesis of achalasia and gastroparesis, and more often, functional pyrosis caused by visceral hypersensitivity, which is treated with pain modulators such as tricyclic antidepressants and serotonin reuptake blockers in low doses ${ }^{(10)}$.

Figure 2 shows the clinical algorithm for the main possibilities of refractory GERD.

Moraes-Filho JPP. Doença do refluxo gastroesofágico refratária. Arq Gastroenterol. 2012;49(4):296-301.

RESUMO - Contexto - A doença do refluxo gastroesofágico (DRGE) é a condição que se desenvolve quando o refluxo do conteúdo gástrico provoca sintomas incômodos e/ou complicações. A fisiopatologia, o diagnóstico e o tratamento da enfermidade têm sido convenientemente estudados, mas é interessante revisar alguns aspectos dos pacientes que são aparentemente refratários, ou seja, não respondem satisfatoriamente ao tratamento com os inibidores da bomba protônica, o que ocorre em $20 \%-42 \%$ dos casos. Aqueles, portanto, que não apresentam resposta terapêutica a um ciclo de 4 a 8 semanas de tratamento com os inibidores da bomba protônica (omeprazol, pantoprazol, rabeprazol, lansoprazol, esomeprazol, pantoprazol-Mg) podem constituir a denominada "DRGE refratária". Resultados - É importante comentar que em alguns casos os pacientes não são realmente refratários ao tratamento, mas podem efetivamente não ter o diagnóstico de DRGE ou até mesmo não terem sido corretamente tratados. Quanto ao estabelecimento diagnóstico, o Consenso Brasileiro da DRGE baseado em evidências sugere a realização da endoscopia digestiva alta como primeiro passo, com o propósito de excluir a presença de úlcera péptica e câncer, além de identificar erosões na mucosa esofágica quando presentes. Conclusões - As principais causas de DRGE refratária são: (1) pirose funcional; (2) baixos níveis de aderência ao tratamento com os inibidores da bomba protônica; (3) dosagem inadequada dos inibidores da bomba protônica; (4) erro diagnóstico; (5) presença de comorbidades e esofagite induzida por comprimidos; (6) diferenças genotípicas; (7) refluxo gastroesofágico não-ácido; (8) doenças autoimunes de pele; (9) esofagite eosinofílica. DESCRITORES - Refluxo gastroesofágico, quimioterapia. Inibidores da bomba de prótons. 


\section{REFERENCES}

1. Abid S, Mumtaz K, Jafri W, Hamid S, Abbas Z, Shah HA, Khan A H. Pill induced esophageal injury: endoscopic features and clinical outcomes. Endoscopy. 2005;37:470-4.

2. Ahlawat SK, Mohi-Ud-Din R, Williams DC, Maher K, Benjamin S. A prospective study of gastric acid analysis and esophageal acid exposure in patients with gastroesophageal reflux refractory to medical therapy. Dig Dis Sci. 2005;50:2019-24.

3. Atkins D, Kramer R, Capocelli K, Lovell M, Furuta GT. Eosinophilic esophagitis: the newest esophageal inflammatory disease. Nat Rev Gastroenterol Hepatol. 2009;6:267-78

4. Barrison AF, Jarboe LA, Weinberg BM, Nimmagadda K, Sullivan LM, Wolfe MM. Patterns of proton pump inhibitor use in clinical practice. Am J Med. 2001;111:469-73.

5. Boeckxstaens GE, Beaumont H, Mertens V, Denison H, Ruth M, Adler J, Silberg DG, Sifrim D. Effects of lesogaberan on reflux and lower esophageal sphincter functions in patients with gastroesophageal reflux disease. Gastroenterology. 2010;139:409-17.

6. Dal-Paz K, Moraes-Filho JPP, Navarro-Rodriguez T, Eisig JN, Barbuti R, Quigley EM. Low levels of adherence with proton pump inhibitor therapy contribute to therapeutic failure in gastroesophageal reflux disease. Dis Esophagus. 2012;25:107-13.

7. de Sousa Cury M, Ferrari AP, Ciconelli R, Ferraz MB, Moraes-Filho JPP. Evaluation of the health-related quality of life in gastroesophageal reflux disease patients before and after treatment with pantoprazole. Dis Esophagus. 2006;19:289-93.

8. Domingues GR, Moraes-Filho JPP, Domingues AG. Impact of prolonged 48-h wireless capsule esophageal $\mathrm{pH}$ monitoring on diagnosis of gastroesophageal reflux disease and evaluation of the relationship between symptoms and reflux episodes. Arq Gastroenterol. 2011;48:24-9.

9. Furuta T, Shirai N, Watanabe F, Honda S, Takeushi K, Iida T, Sato Y, Kajimura M, Futami H, Takayanagi S, Yamada M, Ohashi K, Ishizaki T, Hanai H. Effect of the cytochrome P4502C19 genotypic differences on cure rates for gastroesophageal reflux disease by lansoprazole. Clin Pharmacol Ther 2002;72:453-60.

10. Galmiche JP, Clouse RE, Balint A, Cook IJ, Kahrilas PJ, Paterson WG, Smout AJ. Functional esophageal disorders. Gastroenterology. 2006;130:1459-65.

11. Gerson LB, Huff FJ, Hila A, Hirota WK, Reilley S, Agrawal A, Lal R, Luo W, Castell D. Arbaclofen placarbil decreases postprandial reflux in patients with gastroesophageal reflux disease. Am J Gastroenterol. 2010;105:1266-75.
12. Koek GH, Sifrim D, Lerut T, Janssens J, Tack J. Effect of the GABA(B) agonist baclofen in patients with symptoms and duodeno-gastro-esophageal reflux refractory to proton pump inhibitors. Gut. 2003;52:1397-402.

13. Konikoff MR, Noel RJ, Blanchard C, Kirby C, Jameson SC, Buckmeier, Akers R, Cohen MB, Collins MH, Assa'ad A, Acevess SS, Putnam PE, Rothenberg ME. A randomized, double-blind, placebo-controlled trial of fluticasone propionate for pediatric eosinophilic esophagitis. Gastroenterology. 2006;131:1381-91.

14. Moraes-Filho JP, Chinzon D, Eisig J, Hashimoto CL, Zaterka S. Prevalence of heartburn and gastroesophageal reflux disease in the urban Brazilian population. Arq Gastroenterol. 2005;42:122-7.

15. Moraes-Filho JP, Navarro-Rodriguez T, Eisig JN, Barbuti RC, Chinzon D, Quigley EM. Comorbidities are frequent in patients with gastroesophageal reflux disease in a tertiary health care hospital. Clinics. 2009;64:785-90.

16. Moraes-Filho JPP, Navarro-Rodriguez T, Barbuti R, Eisig J, Chinzon D, Bernardo W; Brazilian Gerd Consensus Group. Guidelines for the diagnosis and management of gastrosophageal reflux disease: an evidence-based consensus. Arq Gastroenterol. 2010;47:99-115.

17. Richter J. How to manage refractory GERD. Nat Clin Pract Gastroenterol Hepatol. 2007;4:658-64.

18. Sifrim D, Holloway R, Silny J, Xin Z, Tack J, Lerut A, Janssen J. Acid, nonacid, and gas reflux in patients with gastroesophageal disease during ambulatory 24hour pH-impedance recordings. Gastroenterology 2001;120:1588-98.

19. Straumann A, Conus S, Degen L, Felder S, Kummer M, Engel H, Bussmann C, Beglinger C, Schoepfer A, Simon HU. Budesonide is effective in adolescent and adult patients with active eosinophilic esophagitis. Gastroenterology. 2010;139:1526-37.

20. Vakil van N, Zanten S, Kahrilas P, Dent J, Jones R; Global Consensus Group. The Montreal definition and classification of gastroesophageal reflux disease: a global evidence-based consensus. Am J Gastroenterol. 2006;101:1900-20.

21. Zerbib F, Roman S, Ropert A, des Varannes SB, Pouderoux P, Chaput U, Mion F, Vérin E, Galmiche JP, Sifrim D. Esophageal pH-impedance monitoring and symptom analysis in GERD: a study in patients off and on therapy. Am J Gastroenterol. 2006;101:1956-63.

Received 11/7/2012. Accepted 16/8/2012. 